\title{
Comprehensive review of models and methods used for heat recovery from composting process
}

\author{
Zhao Rongfei ${ }^{1,2}$, Gao Wei ${ }^{3 *}$, Guo Huiqing ${ }^{2 *}$ \\ (1. College of Water Conservancy, Shenyang Agricultural University, Shenyang 110866, China; \\ 2. Department of Mechanical Engineering, College of Engineering, University of Saskatchewan, 57 Campus Drive, Saskatoon, \\ SK S7N 5A9, Canada; 3. College of Engineering, Shenyang Agricultural University, Shenyang 110866, China)
}

\begin{abstract}
The large amount of heat produced from solid waste composting has stimulated great interest in heat recovery and utilization. This paper reviews the advances in composting heat recovery researches in the last decade. Some experimental results and theoretical studies on composting heat utilization are summarized. The results indicate a great potential for utilization of heat produced by the composting process. Common problems experienced by current methods are how to realize the maximum heat recovery without negatively impacting compost quality and the economics of heat recovery methods. Further advancement of these methods is currently receiving comprehensive interests, both academically and commercially.
\end{abstract}

Keywords: composting, heat recovery, model and method, heat utilization, solid waste

DOI: $10.25165 /$ j.ijabe.20171004.2292

Citation: Zhao R F, Gao W, Guo H Q. Comprehensive review of models and methods used for heat recovery from composting process. Int J Agric \& Biol Eng, 2017; 10(4): 1-12.

\section{Introduction}

Composting has been described as the aerobic degradation of organic wastes where heat is released in the oxygen-consuming microbial metabolism ${ }^{[1]}$. Composting is a significant bio-recycle process ${ }^{[2]}$. It produces huge amount of heat due to heat liberation from microbial metabolic activity. Elevated temperature of the order $70^{\circ} \mathrm{C}-90^{\circ} \mathrm{C}$ may be found within a few days or

Received date: 2015-12-15 Accepted date: 2017-04-07

Biographies: Zhao Rongfei, PhD, Associate Professor, research interest: agricultural soil and water engineering, compost and bioenergy, Email: xngwrf@163.com.

*Corresponding author: Gao Wei, PhD, Lecturer, research interest: biomass preprocessing and bioenergy. College of Engineering, Shenyang Agricultural University, Shenyang 110866, China. Tel: +86-15940146712, Fax: +86-24-88487119, Email: snowwei28@126.com; Huiqing Guo, Professor, research interest: HVAC, air quality control and environment control for agricultural building. Department of Mechanical Engineering, College of Engineering, University of Saskatchewan, Saskatoon, Saskatchewan, S7N 5A9, Canada. Tel: +1-(306) 966-5350, Fax: +1-(306) 966-5350, Email: huiqing.guo@usask.ca. even a few months during the composting of solid organic waste. The temperature increases will lead approximately $85 \%$ of industrial waste to be combustible when heat-loss is unable to balance heat generation ${ }^{[3]}$. The heating-up during a composting process is determined by the degradability and energy content of the substrates $^{[4,5]}$, availability of moisture and oxygen ${ }^{[6-8]}$, $\mathrm{C} / \mathrm{N}$ ratio ${ }^{[9]}, \mathrm{pH}^{[10]}$, and the mode of energy conservation $^{[1,11]}$.

Conventional composting processes typically comprise four major microbiological phases in relation to temperature: mesophilic, thermophilic, cooling and maturation, and the final product is compost ${ }^{[12]}$. The composting processes must be properly managed, and the progressive changes with time of the physical and chemical parameters of the compost must be carefully controlled to give products with optimal qualities. Because compost quality is defined by its maturity and stability, it is determined by quality of the feedstock materials and management of the composting process ${ }^{[13-16]}$.

In order to keep the optimal temperature and meet 
regulatory requirements for pathogen control, current composting approaches and technologies tend to take $55^{\circ} \mathrm{C}$ as the temperature to maintain the appropriate aeration, and thereby shortening the composting process $^{[17-19]}$. Heat removal should be controlled so the temperature in the compost bed is not below $55^{\circ} \mathrm{C}$.

Hence, the objective of this study is to investigate composting processes related to heat recovery, such as optimal heat recovery temperature, potential energy, recovery models, recovery methods and research gaps.

\section{Composting heat}

\subsection{Composting temperature}

According to the best composting temperature ranges, there are two kinds of composting. One is thermophilic composting which works at the temperatures higher than $45^{\circ} \mathrm{C}$. The other is mesophilic composting which is carried out at temperatures lower than $45^{\circ} \mathrm{C}^{[20,21]}$. The best temperatures of these two kinds of composting reported by various researchers are shown in Table $1^{[3,17,22-29]}$. It indicates that mesophilic composting at a lower temperature is more favorable for the decomposition of waste although a higher temperature is effective for the elimination of pathogenic and weed seed contaminants during composting ${ }^{[30,31]}$.

Temperatures should be maintained over $55^{\circ} \mathrm{C}$ for at least $15 \mathrm{~d}$ in thermophilic composting to destroy pathogens, weed seeds and fly larvae and temperatures over $65^{\circ} \mathrm{C}$ should be avoided to prevent immobilization of beneficial microorganisms and minimize the loss of $\mathrm{N}$ during composting ${ }^{[2]}$. The thermophilic phase of the process runs at considerably high temperatures $\left(45^{\circ} \mathrm{C}-65^{\circ} \mathrm{C}\right)$. It lasts several days to 6 weeks, probably owing to the loss of easily degradable organic matter, cooling of the heaps during mechanical turning, or a lack of moisture (below 50\% mass percentage of moisture ${ }^{[32]}$. The optimal moisture content for composting is $50 \%-70 \%{ }^{[7,33]}$. Extending this phase of the composting process may result in shortening the entire process and reducing the amount of harmful gases produced. The higher temperatures $\left(70^{\circ} \mathrm{C}-80^{\circ} \mathrm{C}\right)$ can hygienize the compost, but waste of agricultural origin does not need hygienization $^{[34-36]}$; therefore, the excess heat can be taken away and used in another place. Under the mesophilic composting, the moisture content and $\mathrm{pH}$ could be easily controlled at a level suitable for the growth of microorganisms in the reactor. Comparing with a thermophilic composting at about $60^{\circ} \mathrm{C}$, the mesophilic composting at $35^{\circ} \mathrm{C}$ could bring about a significant reduction of the power input for heating the reactor, and would thus become an option for sanitary disposal of human feces especially in water deficient areas.

Table 1 Composting temperatures reported by various researchers

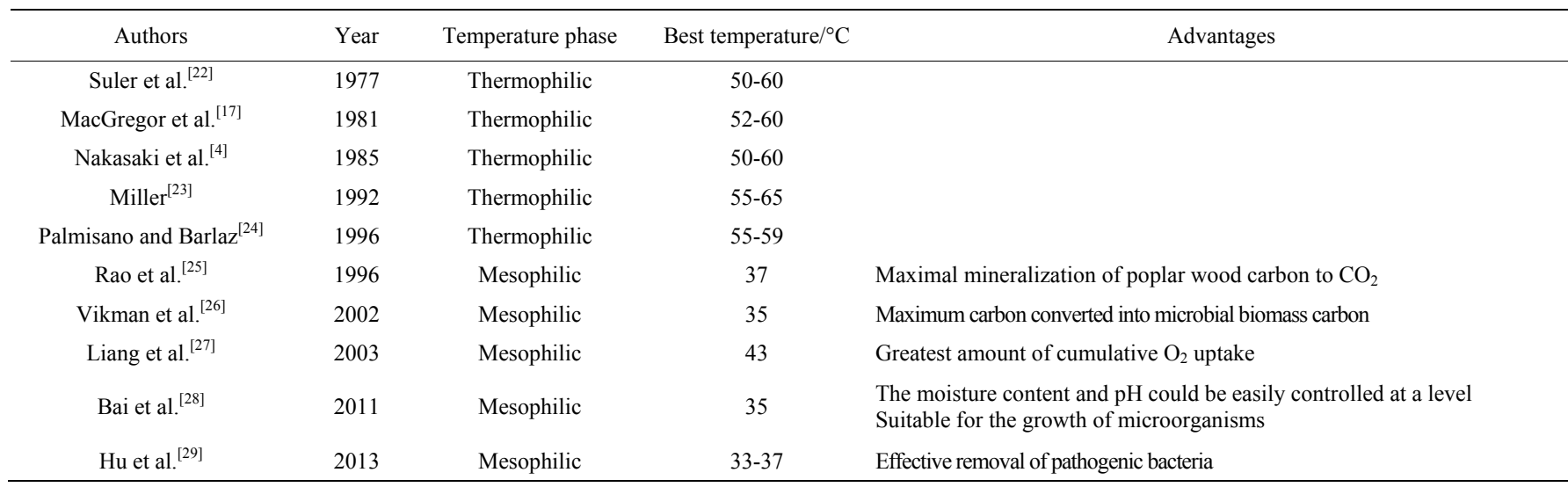

\subsection{Heat production capacity}

Data on the amount of heat produced during composting is scarce, and the results are as diverse as the composition of composted biomass. A limited number of studies have investigated the potential heat production of compost as given is Table $2^{[37-45]}$.

\subsection{Compost thermal conductivity coefficient}

Heat produced in the composting process needs to be released in order to prevent higher than desired temperature. To estimate the heat production, we need to know the thermal conductivity coefficient of the compost materials. Three studies reported the values of 
compost thermal conductivity coefficient as shown in

Table 3. The coefficient is determined by the compost material, compost time, temperature, moisture content and density. It ranges from 0.075 to $0.670 \mathrm{~W} /(\mathrm{m} \cdot \mathrm{K})$. The value has a positive relationship with the compost temperature, moisture content and density ${ }^{[46,47,41]}$.

Table 2 Potential heat production of compost reported by various studies

\begin{tabular}{|c|c|c|c|c|c|}
\hline \multirow{2}{*}{ Authors } & \multirow{2}{*}{ Material } & \multirow{2}{*}{ Year } & \multirow{2}{*}{ Temperature phase } & \multicolumn{2}{|c|}{ Heat production $/ \mathrm{MJ} \cdot \mathrm{kg}^{-1}$} \\
\hline & & & & Average & Range \\
\hline Guljajew and Szapiro $^{[37]}$ & agricultural waste & 1962 & whole & 0.961 & $0.302-1.802$ \\
\hline Stainforth ${ }^{[38]}$ & wheat straw & 1979 & whole & 17.6 & \\
\hline Sobel and Muck ${ }^{[39]}$ & wheat straw & 1983 & whole & 12.8 & \\
\hline Ahn et al. ${ }^{[40]}$ & poultry manure and wood shavings mixture & 2007 & whole & & $16.83-19.7$ \\
\hline Klejment and Rosinski ${ }^{[41]}$ & MSW & 2008 & high temperature phases (higher than $60^{\circ} \mathrm{C}$ ) & 1.136 & \\
\hline Irvine et al. ${ }^{[42]}$ & industrial sludge & 2010 & whole & & $7-10$ \\
\hline Bernstad and Cour ${ }^{[43]}$ & food waste & 2012 & lower heating value & & $1.7-6.3$ \\
\hline Lee et al. ${ }^{[44]}$ & livestock wastes & 2014 & whole & 18.82 & \\
\hline Antonelli et al. ${ }^{[45]}$ & MSW & 2015 & whole & & $9-11$ \\
\hline
\end{tabular}

Table 3 Reported values of compost thermal conductivity coefficient

\begin{tabular}{|c|c|c|c|c|c|c|}
\hline Authors & Material & Year & Moisture content $/ \%$ & Temperature $/{ }^{\circ} \mathrm{C}$ & Density $/ \mathrm{kg} \cdot \mathrm{m}^{-3}$ & Compost thermal conductivity coefficient $/ \mathrm{W} \cdot(\mathrm{m} \cdot \mathrm{K})^{-1}$ \\
\hline Ginkel et al. ${ }^{[46]}$ & straw & 1996 & 75 & $50-60$ & & $0.550-0.670$ \\
\hline Kaleta $^{[47]}$ & clover & 1999 & 40 & $20-80$ & & $0.075-0.085$ \\
\hline
\end{tabular}

\section{Theoretical modeling of compost heat production}

Composting models supply a method to dynamically understand the heating-up and thermal balance process as a system ${ }^{[11]}$. Biological energy production has been predicted using either first-order, Monod-type, or empirical expressions, in conjunction with heat conversion factors. Temperature correction functions have been incorporated into most biological energy models, with corrections for moisture, oxygen and free air space also incorporated in some cases. With simulation results, variations of different thermal balance components could be monitored during the whole composting process, instead of just giving an overall data that indicate which thermal balance component is significant $^{[48]}$.

\subsection{Correction functions of thermal balance components}

\subsubsection{Temperature correction functions}

Experimental composting data show that as temperature rising from about $20^{\circ} \mathrm{C}$, biological activity tends to first increase slowly, then rise moderately to a peak value, following which a rapid decline in activity occurs, typically over a small temperature range. Thus a right-hand skewed curve results, with the optimum and maximum temperatures generally very close together. Similar behavior has been described for other microbial growth studies. A number of models have generated profiles which reflect this phenomenon well ${ }^{[1,49]}$. However, in other cases this pattern has been less well represented. For example, the temperature correction functions used by Kaiser ${ }^{[50]}$ showed parabolically shaped curves, with a high degree of activity indicated at $20^{\circ} \mathrm{C}$, peak temperatures of $40^{\circ} \mathrm{C}$ for all substrates and organisms, and a relatively slow decline above the optimum temperature. A simpler approach was used by Stombaugh and Nokes ${ }^{[51]}$, who adopted three linear temperature correction functions over the ranges $0^{\circ} \mathrm{C}-30^{\circ} \mathrm{C}, 30^{\circ} \mathrm{C}-55^{\circ} \mathrm{C}$ and higher than $55^{\circ} \mathrm{C}$, with a constant value for peak activity from $30^{\circ} \mathrm{C}$ to $55^{\circ} \mathrm{C}$.

The temperature correction model of Neilsen and Berthelsen $^{[52]}$ was based on an enzyme/substrate mechanism in combination with an Arrhenius type expression. It was developed to overcome problems with negative values at high temperature (i.e., above $80^{\circ} \mathrm{C}$ ) occurring with the Haug model ${ }^{[11,52]}$. Whilst it is unlikely that many composting systems would operate at or above $80^{\circ} \mathrm{C}$, the model may be useful for related solid state processes. No validation data was presented. 
In contrast to the models showing a peak, followed by a decrease, in activity, the Arrhenius model utilized by Finger et al. ${ }^{[53]}$ increased exponentially. The empirical model developed by Vandergheynst et al. ${ }^{[54]}$ tended to a plateau at a temperature differential of about $30^{\circ} \mathrm{C}$, which is equivalent to $50^{\circ} \mathrm{C}$ given a starting temperature of $20^{\circ} \mathrm{C}$. However, given the high degree of scatter in the experimental data and evidence of a declining trend in the rate at higher temperatures, a model of the skewed form described above might also be fitted in this case. A polynomial expression for the rate coefficient $k$, with a form similar to the skewed models in their sub-optimal temperature range, was used for temperature correction by Mohee et al. ${ }^{[55]}$. However, a peak and subsequent decrease within the biologically active range was not indicated and the function continued to increase beyond $80^{\circ} \mathrm{C}$.

Three models used to correct for the effect of temperature on the microbial growth rate were evaluated in detail by Richard and Walker, using new experimental $\operatorname{data}^{[49,56-58]}$. Whilst all models showed an acceptable fit, it was concluded that the model of Rosso et al. ${ }^{[49]}$ provided the best description of the rate coefficient temperature dependence, since it involved the fewest parameters, all of which were easily measurable and each of which had a physical meaning in terms of the composting process.

\subsubsection{Moisture, oxygen and FAS correction functions}

Published moisture correction functions employed in composting process models have all been derived empirically. An exponential expression indicating maximum activity at $70 \%$ moisture content was used by Smith and Eilers ${ }^{[59]}$. A similar model, reportedly based on data of Smith and Eilers, was employed by Mohee et al. ${ }^{[55]}$, although in the form presented in the literature, this produces an unrealistic curve. However, following adjustment to ensure that a negative exponent is always present and the moisture content is expressed as a fraction, a curve with a peak at $56 \%$ moisture content may be produced. However, the modified function is negative at fractional moisture levels below $17 \%$ and higher than $97 \%$ and has a different profile to the model of Smith and Eilers $^{[59]}$. In contrast, a function with a plateau above
$70 \%$ was proposed by $\mathrm{Haug}^{[11]}$. As noted by Haug, a decreasing trend in data at higher moisture levels, which was not described by the model, was probably attributable to diminishing free air space. In order to correct for this, Haug also presented a free air space correction function of similar mathematical form to that used for moisture dependence ${ }^{[11]}$. When the moisture and free air space correction functions are combined, a model of similar form to that of Smith and Eilers ${ }^{[59]}$ is produced, illustrating the interdependence of these two factors in terms of their influence on reaction rates. As noted by Haug ${ }^{[11]}$, it can be difficult to separate out the effects of moisture, free air space and also bulk weight. More recently, a mechanistic model relating moisture content and respiration rate has been proposed by Hamelers and Richard ${ }^{[60]}$. This model predicts a relationship of similar form to that generated by the temperature correction model of Rosso et al. ${ }^{[49]}$ and has shown a promising fit to experimental data as reported by Richard et al. ${ }^{[7]}$

The effect of oxygen concentration has been modelled using Monod-type and exponential expressions ${ }^{[11,61]}$. A simple one-parameter model was used by Haug, with a half saturation constant value of $2 \%$. More recently, Richard et al. ${ }^{[61]}$ compared the performance of one-parameter, modified one-parameter and two-parameter Monod-type models, plus an exponential model, using an extensive data set. It was concluded that the Monod-type models gave the best performance over the complete temperature range, and suggested that the simple one parameter model was best suited to windrow composting applications where low oxygen levels may be encountered, whilst the modified one-parameter model may be preferable for forced aeration systems operating at relatively high oxygen concentrations. The simple one-parameter model, with the half saturation constant expressed as an empirical function of temperature and moisture concentration, was subsequently used in the composting model validation study of Higgins and Walker ${ }^{[62]}$.

\subsection{Several important composting energy models}

Nelson et al. ${ }^{[63]}$ analyzed a spatially uniform model based upon Semenov's theory for thermal explosions for 
self-heating in compost piles. The time-derivative of non-dimensional bioreactor temperature $(\mathrm{d} \theta / \mathrm{d} t)$ changed into singularity function $(G)$ is:

$$
G=\psi_{b} \exp [\theta]+\left(\psi_{o} \exp \left[\alpha_{o} \theta\right]-\theta\right)\left(1+\beta \exp \left[\alpha_{d} \theta\right]\right)
$$

Note that,

$$
G_{\psi_{b}}=\exp [\theta] \neq 0
$$

The model investigates the cases when self-heating is due to purely biological heat-release and due to a combination of biological and chemical heat-release. High value of $G$ means temperature increase quickly, low value of $G$ means temperature increase slowly, and negative value of $G$ means temperature decrease. Since the system is described by a single (but non-linear), first-order ordinary differential equation, with few parameters, it is able to investigate the generic steady-state behavior of the system when parameters are varied by using singularity theory ${ }^{[64]}$. This model shows elevated temperatures can be accounted for by two mechanisms. However, it is not validated by experiment.

Sidhu et al. ${ }^{[65]}$ considered a two-dimensional, spatially-dependent model that contains both biological and chemical activity. The relevant equation for the model is:

$$
\begin{gathered}
(\rho C)_{\text {eff }} \frac{\partial T}{\partial t}=k_{\text {eff }} \nabla^{2} T+Q_{c}(1-\varepsilon) \rho_{c} A_{c} \exp \left[\frac{-E_{c}}{R T}\right]+ \\
Q_{b}(1-\varepsilon) \rho_{b} \frac{A_{1} \exp \left[\frac{-E_{1}}{R T}\right]}{1+A_{2} \exp \left[\frac{-E_{2}}{R T}\right]}
\end{gathered}
$$

The formulation of this model is completed once the boundary conditions have been defined. The boundary conditions used in this study are specified in Figure 1, and are given explicitly below.

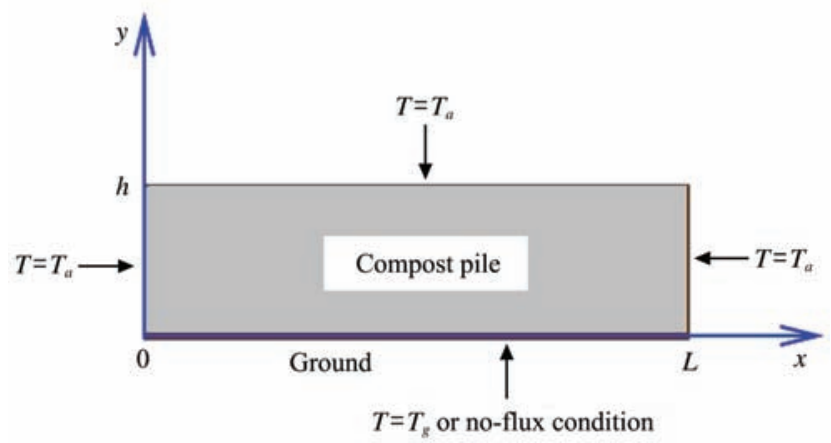

Figure 1 Schematic diagram showing the geometry of the two-dimensional compost pile with a rectangular cross-section and the corresponding boundary conditions ${ }^{[65]}$
Boundary conditions:

$$
\begin{gathered}
T=T_{a}, \text { along } x=0, x=L, \text { and } y=h \\
T=T_{g} \text { or } \frac{\partial T}{\partial n}=0, \text { along the base } y=0
\end{gathered}
$$

Initial conditions:

$$
T=T_{a}
$$

The model incorporates the heat release due to biological activity within the pile and the heat release due to the oxidation of cellulosic materials. The heat release rate due to biological activity is modeled by a function which at sufficiently low temperatures is a monotonic increasing function of temperature. At higher temperatures, it is a monotonic decreasing function of temperature ${ }^{[66]}$. This functionality represents the fact that micro-organisms die or become dormant at high temperatures. The heat release due to the oxidation reaction is modeled by the usual manner using Arrhenius kinetics $^{[65,67]}$. This model is validated by experiment but it does not consider oxygen consumption, and convection of oxygen into the pile.

Boniecki et al. ${ }^{[68]}$ analyzed heat of the composting process of solid natural fertilizers with neural network modeling. This research highlighted the problem of neural prediction of heat processes accompanying the composting of selected natural fertilizers and focused on the estimation of lost heat generated as part of the exothermic reactions taking place during the process. The equation is:

$$
q_{r}=q_{w}+q_{k}=3.6 U A\left(T_{r}-T_{0}\right)+\frac{V \rho}{X+1}\left(i_{w}-i\right)
$$

The research results show that neural network modeling can be effectively used in the process of estimating heat energy emitted and lost in the composting process. The model's analysis of sensitivity to input variables show that the six most important parameters in the process of neural estimation of heat lost are in the following order: $T$ (temperature inside the bioreactor), $S M$ (mineral substance mass), $\mathrm{O}_{2}$ (\% volume percentage of oxygen), $V$ (stream volume), $\mathrm{CO}_{2}(\%$ volume percentage of carbon dioxide), and $t$ (process duration).

Wang et al. ${ }^{[69]}$ developed a thermal balance model for composting process to determine variations of heat loss components (conduction, convection and latent heat loss) 
during the process. The thermal balance equation is:

$$
\left(m c+m_{R} c_{R}\right) \frac{d T}{d t}=E_{b i o}-E_{\text {con }}-E_{\text {wall }}-E_{\text {lat }}
$$

Model results in this study show that the percentages of convective, conductive and latent heat losses of total heat loss varied significantly during the composting process. The peak percentages of conduction heat losses are $38.9 \%$ and $57.7 \%$ of total heat losses for the modeling situation with and without insulation, respectively. Substrate decomposition could significantly affect temperature changes and the whole thermal balance process.

Khater et al. ${ }^{[70]}$ developed a mathematical model to predict the compost temperature during the maturation stage. The components of the energy balance of the compost pile which include: heat gained (heat generation and solar radiation) and heat lost (radiation, evaporation, convection and conduction) at different ambient temperatures. The heat balance equation of the compost pile is:

$$
m C_{P} \frac{d T}{d t}=Q_{\text {gen }}+Q_{\text {solar }}-Q_{\text {evap }}-Q_{\text {conv }}-Q_{\text {cond }}-Q_{\text {rad }}
$$

This model is able to predict the pile temperature at different ambient temperatures and different airflow rates. The results show that the pile temperature increases with increasing ambient temperature and it decreases with increasing airflow rates, where, as the ambient temperature increases from $15^{\circ} \mathrm{C}$ to $35^{\circ} \mathrm{C}$, the pile temperature increases from $33.40^{\circ} \mathrm{C}$ to $37.41^{\circ} \mathrm{C}$, and when the airflow rates increases from $0.7 \mathrm{mg}$ air/s $\mathrm{kg}$ dry matter to $1.5 \mathrm{mg}$ air/s $\mathrm{kg}$ dry matter, the pile temperature decreases from $34.40^{\circ} \mathrm{C}$ to $32.39^{\circ} \mathrm{C}$. The pile temperature increases slightly and reaches a maximum value at day 14. It indicates that the net energy gained to the pile increases with increasing ambient temperature, meanwhile, the heat lost decreases with increasing ambient temperature. The model results indicate that the predicted daily temperature is in a reasonable agreement with those measured ones and other data in literature $^{[40,71]}$ at different ambient temperatures and airflow rates, where, it ranges from $30.30^{\circ} \mathrm{C}$ to $73.40^{\circ} \mathrm{C}$, while it is from $18.0^{\circ} \mathrm{C}$ to $71.0^{\circ} \mathrm{C}$ experimentally during the whole period of compost maturation ${ }^{[40,71]}$. The calculated results of this model are consistent with the experiments and consider the ambient temperature and the airflow rates.

\section{Heat recovery methods}

A limited number of experimental studies on compost heat recovery have been reported. One major problem during the studies is the precision in controlling the processes of heat removal and aeration in the bed. Too much heat removal from a heap may result in a temperature drop inside it, which, in effect, can slow down (or even stop) the thermophilic phase of composting $^{[72]}$. On the other side, too intensive aeration results in desiccation of the composting material and simultaneous loss of heat; and too little aeration slows down the composting process. The process control methods currently in use are usually based on adjusting the amount of air supplied to a compost heap by controlling either the temperature inside the bed or the oxygen content of the air which leaves the heap ${ }^{[73]}$. There are direct and indirect methods of heat recovery from composting.

\subsection{Direct recovery method}

A direct recovery method involves extracting heat from the material during the composting process.

\subsubsection{Water heating}

The first method involves recirculating water through tubing buried within a compost pile or concrete slab. Smith and Aber ${ }^{[74]}$ reported that "this method is more suitable for backyard operations, where the time and labor consuming aspects of installing and removing the pipe during pile formation and breakdown, can be absorbed by an enthusiastic homeowner". They concluded that this scenario "is not typically suitable for a commercial practice where revenue is the goal, as it is labor/time intensive". Another problem is that mechanized agitation can be restricted by the pipes in the compost pile. Problems can also arise if too much heat is removed from the pile by the cold water. This scenario can inhibit microbial growth and crash the microbial population, causing putrid conditions ${ }^{[74]}$.

A simple and efficient method of directly extracting heat energy from manure was pioneered by Gorton ${ }^{[75]}$ in 
which a litter pile is built in 10 inch thick layers with water pipes in between each layer. As air flows through the litter pile, the compost heat is transferred to the water in the pipes and then the pipes carry the heated water to a greenhouse as a source of radiant heat. Courtney ${ }^{[76]}$ utilized such a system. It is a hydraulic system in which water is passed through the compost in a system of recirculating pipes traveling into the greenhouse and back to the pile (Figure 2). When the water reaches the greenhouse, it would pass through a heat exchanger to warm the air of the greenhouse ${ }^{[76]}$.

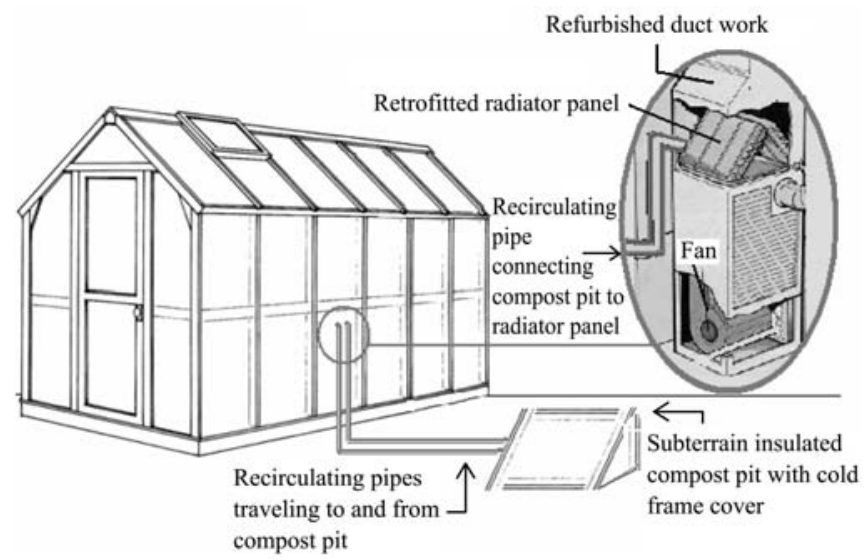

Figure 2 Heat exchange system (designed by Booker) ${ }^{[59]}$

Lekic $^{[77]}$ investigated the increase in water temperature between the inlet and the outlet of polyethylene pipes embedded in composting windrows and reports that $73 \%$ of the theoretical value of heat energy is transferred to the water. One main limitation of this study is the placement of the pipes within the compost mass. A solution proposed by Seki and Komori $^{[78]}$ involved using a packed column heating tower that transfers the heat from the warm exhaust air of the compost to a volume of water.

\subsubsection{Space heating}

The second approach used to recover heat from composting is through space heating, where heat is pushed out (forced aeration) or pulled through (negative aeration) a composting pile. Smith and Aber ${ }^{[74]}$ described how this is "most commonly accomplished by placing compost on top of an aeration floor, where perforated PVC pipes are cast into concrete, covered by a perforated cover plate, which is then covered by 8 " of woodchips. By mechanically moving air through the pile, the aerobic microbes receive needed oxygen, while excess heat is removed, both of which allow for a larger and healthier microbial population ${ }^{[74,79,80]}$. Heat recovery from a positive aeration system is one option, but has limited applications due to the difficulty in capturing the diffused heat across the pile. The amount of available heat is also limited, as only $13.4 \%$ of the heat generated within the pile is contained in the airflow ${ }^{[81]}$. Early research utilizing this technology came from the New Alchemy Institute, where a winter greenhouse was warmed through compost vapor, which had been sent through a biofilter ${ }^{[82]}$. Although limited to mostly horticultural applications, this method serves as a valuable tool for season extension and energy reduction for greenhouse in cooler climates" $^{[74,83,84]}$. One example to capture and utilize this heat is University of New Hampshire (UNH) heat recovery composting facility shown in Figures 3 and $4^{[74,83,84]}$. It can handle up to $400 \mathrm{t} / \mathrm{month}$ of feedstock. UNH heat recovery unit captures both the thermal energy in the hot air and in the water molecules of the vapor stream itself. It can maintain 295-gallon water tank at an average of $37.8^{\circ} \mathrm{C}^{[83]}$.
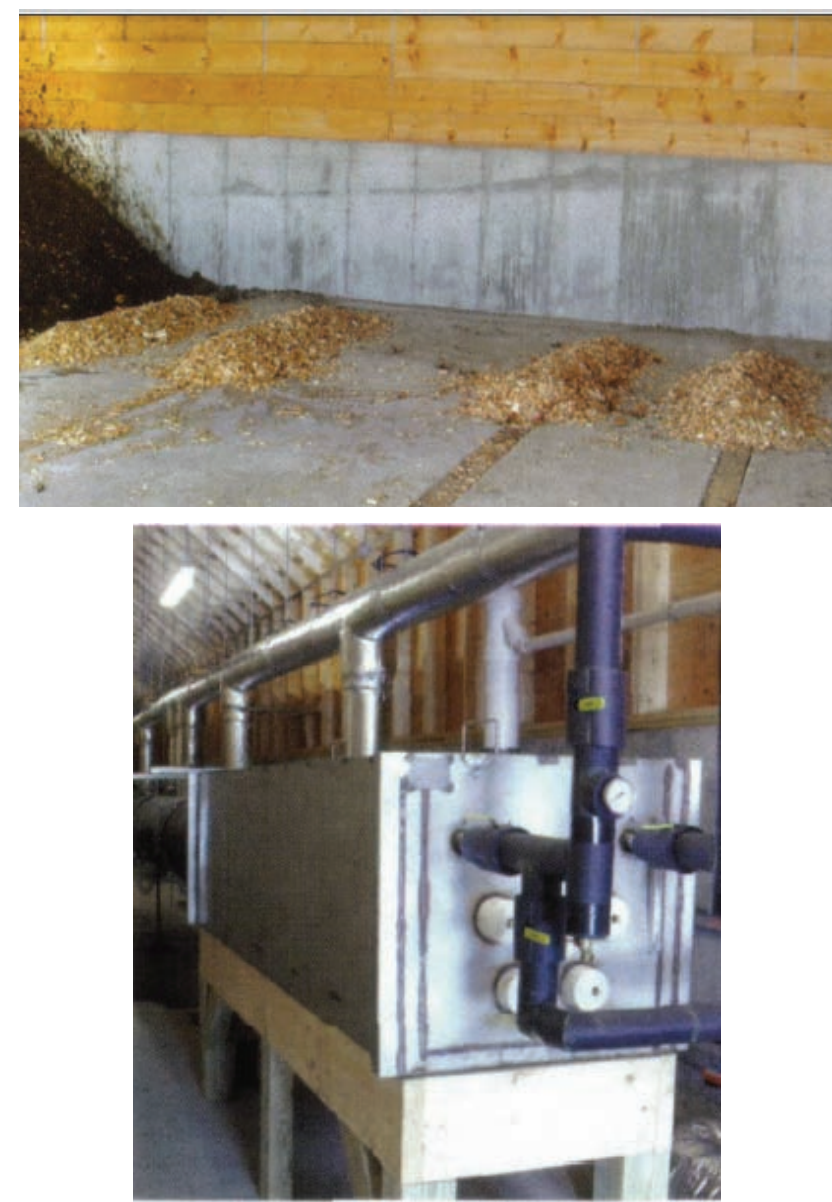

Figure 3 Heat capture system ${ }^{[83]}$ 


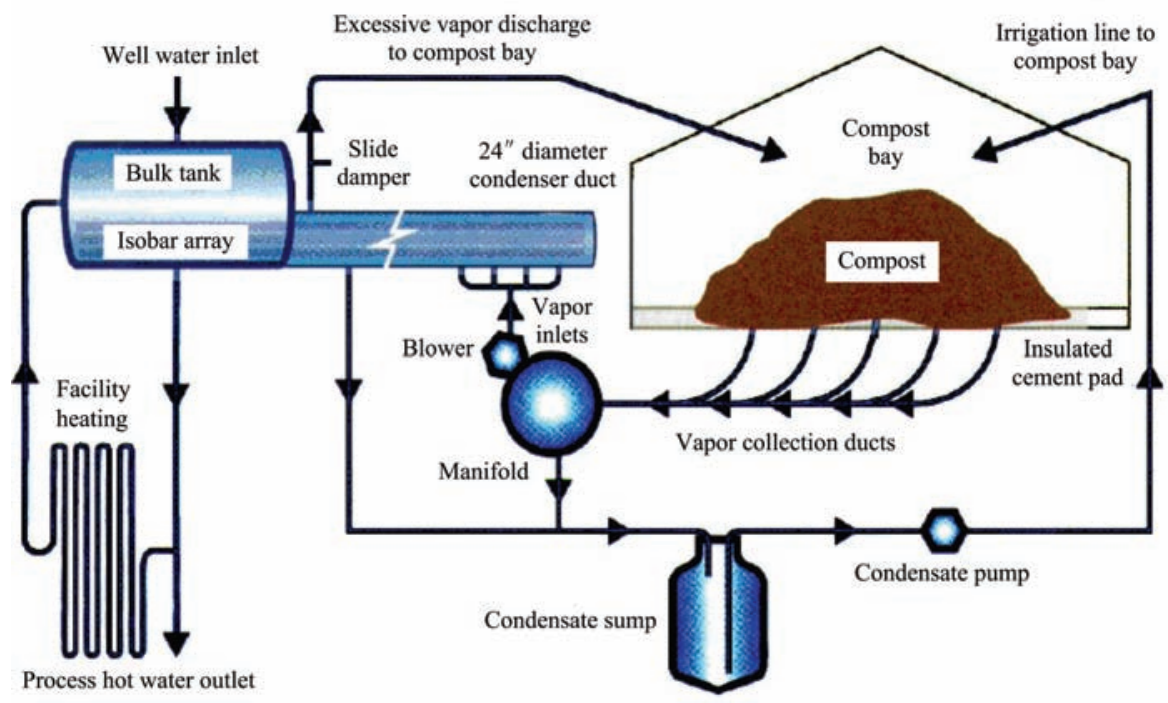

Figure 4 Flow diagram of UNH heat recovery system ${ }^{[83]}$

\subsection{Indirect recovery method}

An indirect recovery method involves harvesting the heat indirectly by altering the form of the bio-waste material itself. Lee et al. ${ }^{[44]}$ reformed an advanced compost and energy system (ACES). They reported that "in the ACES, technically, high water content in livestock wastes evaporated by an exothermal reaction caused from a specific group of aerobic fermentation microorganisms. The microorganisms produce heat higher than $80^{\circ} \mathrm{C}$ thus evaporating moisture retained in wastes. Livestock wastes and food wastes are comparatively tested. Resulting materials show relatively high caloric value and energy yield, $18.82 \mathrm{MJ} / \mathrm{kg}$, in a heating value test. Among many advantages of the ACES, a wastewater treatment process is not needed for the liquid separation from slurry waste. Rather, unlike conventional methods, the ACES is more like a zero discharge system, not using external energy sources. By exothermic reaction, microorganisms heat out while digesting organic compounds of livestock waste. The temperature from the ACES is up to $80^{\circ} \mathrm{C}-90^{\circ} \mathrm{C}$. With this heat, moisture inside of the waste is removed from a slurry waste, which other methods are not able to do" [44]

The biggest obstacle to convert livestock or food wastes to energy material is how to separate liquid from livestock waste and dispose of or treat the liquid part. The moisture content of livestock and food waste is up to $90 \%$. If liquid out of this high slurry waste is appropriately managed, the remaining solid, as an organic mass, is apt to have a relatively high energy yield, such as
10.46-14.64 MJ/kg. In order to evaporate internal moisture out of high slurry waste, high energy demanding methods are conventionally used. In other words, it requires high costs to use electricity and gas for liquid evaporation. In addition, it is time consuming to completely dry slurry waste because moisture inside of the waste is not easily dried out. With this water content, a dried material is also odorous ${ }^{[79]}$. The ACES is advantageous in high water content wastes composting.

\section{Conclusions}

Recent researches have acquired many of achievements in the field of theory and experiment about composting heat recovery. Some heat recovery methods have been practiced in agricultural and industrial production. The potential energy content of poultry manure and wood shavings mixture composting is the highest, the values range from $16.83 \mathrm{MJ} / \mathrm{kg}$ to $19.7 \mathrm{MJ} / \mathrm{kg}$. Direct recovery method is the most used in the industrial composting due to its simplicity. The heat transfer calculation models normally could be used to simulate the specified composting process.

Research is needed to develop simplified models for heating predictions in the ordinary conditions with the main influence factors of compost, such as temperature, time, moisture, density and oxygen. Meantime, highly efficient heat recovery method from compost should be commercialized. The keys to success have been new methods of managing aeration, combined with innovative heat exchangers. Negatively aerated static pile systems 
(pulling air down through the top of the material into channels underneath it) enable heat to be captured by running the hot vapor pulled from the compost through a heat exchanger. Negative aeration also enables capture of carbon dioxide $\left(\mathrm{CO}_{2}\right)$ emissions and odors from compost.

\section{Acknowledgements}

The authors would like to express their gratitude towards the financial support received from the National Natural Science Foundation of China (Grant No: 51508345), the National Sparking Plan Project (2015GA650012), the Cultivation Plan for Youth Agricultural Science and Technology Innovative Talents of Liaoning Province (2014053).

\section{Nomenclature}

$\psi_{b} \quad$ semenov number for the biomass

$X \quad$ absolute mass humidity of surrounding air

$\Theta$ non-dimensionalized bioreactor temperature, $\mathrm{K}$

$A_{2}$ pre-exponential factor for the inhibition of biomass growth

$\psi_{o}$ semenov number for the oxidation of cellulosic materials

$T_{g} \quad$ temperature of the ground, $\mathrm{K}$

$\alpha_{o}$ dimensionalized activation energy for cellulose oxidation

$q_{r} \quad$ amount of heat generated (lost) in the bioreactor, $\mathrm{kJ} / \mathrm{h}$

$\beta \quad$ maximum dimensionless rate of inhibition

$T_{a}$ ambient temperature, $\mathrm{K}$

$U$ penetration coefficient, $\mathrm{W} /\left(\mathrm{m}^{2} \cdot \mathrm{K}\right)$

$E_{1}$ activation energy for the biomass growth, $\mathrm{J} / \mathrm{mol}$

$T$ temperature within the compost pile, $\mathrm{K}$

A bioreactor surface, $\mathrm{m}^{2}$

$t$ time, $\mathrm{s}$

$T_{r} \quad$ medium temperature of the bioreactor, $\mathrm{K}$

$k_{\text {eff }}$ effective thermal conductivity of the bed, $\mathrm{W} /(\mathrm{mK})$

$E_{2}$ activation energy for the inhibition of biomass growth, $\mathrm{J} / \mathrm{mol}$

$E$ void fraction, -

$T_{0} \quad$ external temperature, $\mathrm{K}$

$\rho_{c} \quad$ density of pure cellulosic material, $\mathrm{kg} / \mathrm{m}^{3}$

$\rho \quad$ density of input air, $\mathrm{kg} / \mathrm{m}^{3}$
$R \quad$ ideal gas constant, $\mathrm{J} / \mathrm{K} \cdot \mathrm{mol}$

$P_{b}$ density of bulk biomass within the compost pile, $\mathrm{kg} / \mathrm{m}^{3}$

$V$ volume stream of air on the inlet to the bioreactor, $\mathrm{m}^{3} / \mathrm{h}$

$m$ mass of composting materials, $\mathrm{kg}$

$i \quad$ absolute enthalpy of the inlet air, $\mathrm{kJ} / \mathrm{kg}$

$c$ specific heat capacity of composting materials, $\mathrm{kJ} /\left(\mathrm{kg} \cdot{ }^{\circ} \mathrm{C}\right)$

$m_{R}$ mass of composting reactor, $\mathrm{kg}$

$c_{R}$ specific heat capacity of composting reactor, $\mathrm{kJ} /\left(\mathrm{kg} \cdot{ }^{\circ} \mathrm{C}\right)$

$E_{b i o}$ biological heat production, $\mathrm{kJ} / \mathrm{d}$

$E_{c o n}$ convective heat loss, $\mathrm{kJ} / \mathrm{d}$

$E_{\text {wall }}$ conductive heat loss form surface of reactor, $\mathrm{kJ} / \mathrm{d}$

$E_{\text {lat }}$ latent heat of water evaporation, $\mathrm{kJ} / \mathrm{d}$

$Q_{b}$ exothermicity for the oxidation of biomass per $\mathrm{kg}$ of dry cellulose, $\mathrm{J} / \mathrm{kg}$

$C_{P}$ heat capacity of compost, $\mathrm{kJ} /\left(\mathrm{kg} \cdot{ }^{\circ} \mathrm{C}\right)$

$Q_{c}$ exothermicity for the oxidation of the cellulosic material, $\mathrm{J} / \mathrm{kg}$

$Q_{\text {gen }}$ generated energy by biodegradation, $\mathrm{kJ} / \mathrm{d}$

$A_{1}$ pre-exponential factor for the oxidation of the biomass growth, $1 / \mathrm{s}$

$Q_{\text {solar }}$ generated energy by solar radiation, $\mathrm{kJ} / \mathrm{d}$

$A_{c}$ pre-exponential factor for the oxidation of the cellulosic material, $1 / \mathrm{s}$

$Q_{\text {evap }}$ energy loss by water evaporation, $\mathrm{kJ} / \mathrm{d}$

$E_{c}$ activation Energy for the oxidation of the cellulosic material, $\mathrm{J} / \mathrm{mol}$

$Q_{\text {conv }}$ energy loss by convection, $\mathrm{kJ} / \mathrm{d}$

$\alpha_{d}$ dimensionless activation energy for the inhibition of biomass growth

$Q_{\text {cond }}$ energy loss by conduction, $\mathrm{kJ} / \mathrm{d}$

$\left(\rho_{C}\right)_{\text {eff }}$ effective thermal capacity per unit volume of the bed, $\mathrm{J} /\left(\mathrm{m}^{3} \cdot \mathrm{K}\right)$

$Q_{\text {rad }}$ energy loss by radiation, $\mathrm{kJ} / \mathrm{d}$

$q_{w}$ heat leaving the bioreactor as a result of the penetration phenomenon, $\mathrm{kJ} / \mathrm{h}$

$q_{k}$ heat leaving the bioreactor as a result of the convection phenomenon, $\mathrm{kJ} / \mathrm{h}$

$i_{w}$ absolute enthalpy of air on the outlet of the bioreactor, $\mathrm{kJ} / \mathrm{kg}$ 


\section{[References]}

[1] Sundberg C. Food waste composting-effects of heat, acids and size. Licentiate Thesis. Sweden, Uppsala: Swedish University of Agriculture Sciences, 2004.

[2] Rynk R. Fires at composting facilities: causes and conditions. BioCycle Magazine, 2000; 41(1): 54-58.

[3] Hogland W, Bramryd T, Persson I. Physical, biological and chemical effects of unsorted fractions of industrial solid waste in waste fuel storage. Waste Mgt Res, 1996; 14(2): 197-210.

[4] Nakasaki K, Sasaki M, Shoda M, Kubota H. Change in microbial numbers during thermophilic composting of sewage sludges with reference to $\mathrm{CO}_{2}$ evolution rate. Applied and Environmental Microbiology, 1985; 49(1): $37-41$.

[5] Weppen P. Process calorimetry on composting of municipal organic wastes. Biomass and Bioenergy, 2001; 21: 289-299.

[6] Garcia M, Otero D, Mato S. New bulking agents for composting sewage sludge (pteridium $\mathrm{sp}$. and ulex $\mathrm{sp}$.), a laboratory scale evaluation. In: M. de Bertoldi et al. (Eds.), The Science of Composting. An Imprint of Chapman \& Hall, 1996; pp.1170-1173.

[7] Richard T L, Hamelers H V M, Yeeken A, Silva T. Moisture relationship in composting process. Composting Science and Utilization, 2002; 10(4): 286-302.

[8] Arslan E I, ünlü A, Topal M. Determination of the effect of aeration rate on composting of vegetable fruit wastes. Clean-Soil, Air, Water, 2011; 39(11): 1014-1021.

[9] Nakasaki K, Yaguchi H, Sasaki Y, Kubota H. Effects of $\mathrm{C} / \mathrm{N}$ ratio on thermophilic composting of garbage. Journal of Fermentation and Bioengineering, 1992; 73(1): 43-45.

[10] Dougherty M. Field guide to on farm composting. Natural Resource, Agriculture and Engineering Service, Ithaca, NY. Publication No. NRAES-114, 1999.

[11] Haug R T. Practical handbook of compost engineering. Lewis Publishers, Boca, Raton, FL, USA. 1993.

[12] Haug R T. Compost engineering: Principles \& practice, Ann Arbor Science Publishers, Ann Arbor, Mich, USA. 1980.

[13] Bernard E, Larkin R P, Tavantzis S M, Erich M S, Alyokhin A, Sewell G, Lannan A, Gross S. Compost, rapeseed rotation, and biocontrol agents significantly impact soil microbial communities in organic and conventional potato production systems. Applied Soil Ecology, 2012; 52: 29-41.

[14] Butler T A, Sikora L J, Steinhilber P M, Douglass L W. Compost age and sample storage effects on maturity indicators of biosolids compost. Environ Qual, 2001; 30: 2141-2148.
[15] Gomez R B, Lima F V, Ferrer A S. The use of respiration indices in the composting process: a review. Waste Mgt Res, 2006; 24: 37-47.

[16] Carballo T, Gill V M, Gómez X, González-Andrés F, Morán A. Characterization of different compost extracts using Fourier-transform infrared spectroscopy (FTIR) and thermal analysis. Biodegradation, 2008; 19: 815-830.

[17] MacGregor S T, Miller F C, Psarianos K M, Finstein M S. Composting process control based on interaction between microbial heat output and temperature. Appl Environ Microbiol, 1981; 41(6): 1321-1330.

[18] EC, EU Animal By-Products Regulations (2003/31/EEC). European Commission. 2003.

[19] Neugebauer M, Sołowiej P, Piechocki J. Fuzzy control for the process of heat removal during the composting of agricultural waste. J Mater Cycles Waste. 2014; 16: 291-297.

[20] Mbah B N, Odili P N. Changes in moisture retention properties of five waste materials during short-term mesophilic composting. Compost Sci Util, 1998; 6(4): $67-73$.

[21] Adler P R. Effect of a temporal carbon gradient on nitrogen and phosphorus dynamics and decomposition during mesophilic composting. Communications in Soil Science and Plant Analysis, 2005; 36: 2047-2058.

[22] Suler D J, Finstein M S. Effect of temperature, aeration, and moisture on $\mathrm{CO}_{2}$ formation in bench-scale, continuously thermophilic composting of solid waste. Applied and Environmental Microbiology, 1977; 33(2): 345-350.

[23] Miller F G. Composting as a process based on the control of ecologically selective factors. In: Metting FB (ed) Soil Microbial Ecology, Dekker, New York. 1993; 515-544.

[24] Palmisano A, Barlaz M. Microbiology of Soil Waste. CRC Press. Boca Rate, FL. 1996; 121-134.

[25] Rao N, Grethlein H E, Reddy C A. Effect of temperature on composting of atrazine amended lignocellulosic substrates. Compost Sci Util, 1996; 4: 83-88.

[26] Vikman M, Karjomaa S, Kapanen A, Wallenius K, Itavaara M. The influence of lignin content and temperature on the biodegradation of lignocellulose in composting conditions. Appl Environ Microbiol, 2002; 59: 591-598.

[27] Liang C, Das K C, McClendon R W. The influence of temperature and moisture contents regimes on the aerobic microbial activity of a biosolids composting blend. Bioresour Technol, 2003; 86: 131-137.

[28] Bai F, Wang X C. Study on characteristics of fecal organic matters degradation in an aerobic composting reactor under mesophilic condition. Chinese Journal of Environmental Engineering, 2011; 5(8): 1863-1866. (in Chinese)

[29] Hu T, ang X C, Li Q, Shi H L, Bai F. A pilot scale study on 
a human feces composting in aerobic medium temperature composting reactor. Chinese Journal of Environmental Engineering, 2013; 7(12): 4965-4970. (in Chinese)

[30] Grundy A C, Green J M, Lennartsson M. The effect of temperature on the viability of weed seeds in compost. Compost Sci Util, 1998; 6: 26-33.

[31] Elorriota M A, Suarez-Estrella F, Lopez M J, Vargas-Garcia M C, Moreno J. Survival of phytopathogenic bacteria during waste composting. Agr Ecosyst Environ, 2003; 96: 141-146.

[32] Raclavska H, Juchelkova D, Skrobankova H. Conditions for energy generation as an alternative approach to compost utilization. Environmental Technology, 2011; 32(4): 407-417.

[33] Vergnoux A, Guiliano M, Le Dréau Y, Dupuy N. Monitoring of the evolution of some compost properties by NIR spectroscopy. Sci Total Environ, 2009; 407: 2390-2403.

[34] Bari Q H, Koenig A. Effect of air recirculation and reuse on composting of organic solid waste. Res Cons Recycle, 2001; 33: 93-111.

[35] Ekinci K, Keener H M, Akbolat D. Effects of feedstock, airflow rate, and recirculation ratio on performance of composting systems with air recirculation. Bioresource Technology, 2006; 97: 922-932.

[36] Lin C. A negative-pressure aeration system for composting food waste. Biores Technol, 2008; 99: 7651-7656.

[37] Guljajew N, Szapiro M. Determining of heat energy volume released by waste during biothermal disposal. Sbornik naucznych robot. Akademija Kommunalnowo Chozjajstwa, Moskow, Russia, 1962; 135-141.

[38] Stainforth A. Cereal Straw, Clarendon, Oxford, UK. 1979.

[39] Sobel A T, Muck R E. Energy in animal manures. Energy in Agriculture, 1983; 2: 161-176.

[40] Ahn H k, Richard T L, Choi H L. Mass and thermal balance during composting of a poultry manure-wood shavings mixture at different aeration rates. Process Biochem, 2007; 42(2): 215-223.

[41] Klejment E, Rosinski M. Testing of thermal properties of compost from municipal waste with a view to using it as a renewable, low temperature heat source. Bio-resource Technology, 2008; 99(18): 8850-8855.

[42] Irvine G, Lamont E R, Ladislao B A. Energy from waste: reuse of compost heat as a source of renewable energy. Int $J$ Chem Eng, 2010; 2010(3): 1-10.

[43] Bernstad A, la Cour J. Review of comparative LCAs of food waste management systems current status and potential improvements. Waste Manage, 2012; 32(12): 2439-2455.

[44] Lee H S, Kim D, Park J S, Chilingar G V. Advanced compost and energy (ACE) system converting livestock wastes to resources by exothermal microbial reactions: a case study. Energy Sources, Part A, 2014; 36: 1507-1516.

[45] Antonelli M, Baccioli A, Francesconi M, Psaroudakis P, Martorano L. Technologies for Energy Recovery from Waste Biomasses: A Study about Tuscan Potentialities, 2015; 81(12): 450-460.

[46] Ginkel J T, Raats P A C, Haneghem V. Physical and biochemical processes in composting material. Agricultural University of Wageningen, Wageningen, the Netherlands. 1996.

[47] Kaleta A. Thermal properties of plant materials. Warsaw Agricultural University Press, Warsaw, Poland, 1999.

[48] Mason I G. Mathematical modeling of the composting process: a review. Waste Manage, 2006; 26(1): 3-21.

[49] Rosso L, Lobry J R, Flandrois J P. An unexpected correlation between cardinal temperatures of microbial growth highlighted by a new model. J theor Biol, 1993; 162: $447-463$.

[50] Kaiser J. Modelling composting as a microbial ecosystem: a simulation approach. Ecological Modelling, 1996; 91(1-3): 25-37.

[51] Stombaugh D P, Nokes S E. Development of a biologically based aerobic composting simulation model. Transactions of ASAE, 1996; 39(1): 239-250.

[52] Neilsen H, Berthelsen L. A model for the temperature dependency of thermophilic composting rate. Compost Science and Utilisation, 2002; 10(3): 249-257.

[53] Finger S M, Hatch R T, Regan T M. Aerobic microbial growth in semi-solid matrices: heat and mass transfer limitations. Biotechnology and Bioengineering, 1976; 18(9): 1193-1218.

[54] Vandergheynst J S, Walker L P, Parlange J Y. Energy transport in a high-solids aerobic degradation process: Mathematical modeling and analysis. Biotechnology Progress, 2008; 13(3): 238-248.

[55] Mohee R, White R K, Das K C. Simulation model for composting cellulosic (bagasse) substrates. Compost Science and Utilisation, 1998; 6(2): 82-92.

[56] Andrews J F, Kambhu K. Thermophilic aerobic digestion of organic solid wastes. EPA-670/2-73-061, PB-222 396, USEPA, Springfield, IL, USA. 1973.

[57] Ratkowsky D A, Lowry R K, McMeekin T A, Stokes A N, Chandler R E. Model for bacterial culture and growth rate throughout the entire biokinetic temperature range. Journal of Bacteriology, 1983; 154(3): 1222-1226.

[58] Richard T L, Walker L P. Modeling the temperature kinetics of aerobic solid-state biodegradation. Biotechnology Progress, 2006; 22(1): 70-77.

[59] Smith R, Eilers R G. Numerical simulation of activated sludge composting. EPA-600/2-8C-191, USEPA, Cincinnati, OH, USA. 1980. 
[60] Hamelers B V F, Richard T L. The effect of dry matter on the composting rate: Theoretical analysis and practical implications. ASAE paper 017004, ASAE, St Joseph, MI, USA. 2001

[61] Richard T L, Walker L P, Gossett J M. Effects of oxygen on aerobic solid-state biodegradation kinetics. Biotechnology Progress, 2006; 22(1): 60-69.

[62] Higgins C, Walker L. Validation of a new model for aerobic organic solids decomposition: simulations with substrate specific kinetics. Process Biochemistry, 2001; 36(8-9): 875-884.

[63] Nelson M I, Balakrishnan E, Chen X D. A Semenov model of self-heating in compost piles. Transactions of I Chem E. Part B, 2003; 81: 375-383.

[64] Golubitsky M, Schaeffer D. The classification theorem in singularities and groups in bifurcation theory. 1st edition, Springer, Berlin, Germany. 1985.

[65] Sidhu H S, Nelson M I, Chen X D. Mathematical modeling of the self-heating process in compost piles. Chemical Product and Process Modeling, 2007.

[66] Nelson M I, Marchanta T R, Wake G C, Balakrishnan E. Self-heating in compost piles due to biological effects. Chemical Engineering Science, 2007; 62: 4612-4619.

[67] Luangwilai T, Sidhu H S, Nelson M I. Modelling air flow and ambient temperature effects on the biological self-heating of compost piles. Asia-Pac J Chem Eng, 2010; 5: 609-618.

[68] Boniecki P, Dach J, Mueller W, Koszela K. Neural prediction of heat loss in the pig manure composting process. Applied Thermal Engineering, 2013; 58: 650-655.

[69] Wang Y J, Huang G Q, Zhang A Q, Han L J. Estimating thermal balance during composting of swine manure and wheat straw: A simulation method. International Journal of Heat and Mass Transfer, 2014; 75: 362-367.

[70] Khater E G, Bahnasawy A H, Ali S A. Mathematical model of compost pile temperature prediction. J Environ Anal Toxicol, 2014; 4(6): 242.

[71] Barrena R, Canovas C, Sánchez A. Prediction of temperature and thermal inertia effect in the maturation stage and stockpiling of a large composting mass. Waste Management, 2006; 26(9): 953-959.

[72] Chroni C, Kyriacou A, Georgaki I, Manios T. Microbial characterization during composting of biowaste. Waste Manag (Oxford), 2009; 29: 1520-1525.

[73] Xiao Y, Zeng G M, Yang Z H. Continuous thermophilic composting (CTC) for rapid biodegradation and maturation of organic municipal solid waste. Biores Technol, 2009; 100: 4807-4813.

[74] Smith M M, Aber J D. Heat Recovery from Compost: A guide to building an aerated static pile heat recovery composting facility. UNH cooperative Extension. 2014.

[75] Gorton S. Is it really possible to extract heat from compost to warm your barn, greenhouse or home? A grassroots research network is finding out. Cornell Small Farms Program, 2012.

[76] Courtney G. Designing a compost-heated greenhouse to foster sustainable food security, Faculty of Environment, Department of Environment and Resource Studies, University of Waterloo, Waterloo, Ontario, Canada, 2009.

[77] Lekic S. Possibilities of Heat Recovery from Waste Composting Process, Centre for Sustainable Development, Department of Engineering, University of Cambridge, Cambridge, UK. 2005.

[78] Seki H, Komori T. Packed-column-type heating tower for recovery of heat generated in compost. Journal of Agricultural Meteorology, 1992; 48(3): 237-246.

[79] Smith M M. Creating an economically viable, closed system, energy-independent dairy farm through the on farm production of animal bedding and heat capture from an aerated static pile heat recovery composting operation. $\mathrm{PhD}$ dissertation. Durham: University of New Hampshire, 2016.

[80] Epstein E. Industrial composting: environmental engineering and facilities management. Boca Raton, FL: CRC Press, 2011.

[81] Seki H, Kiyose S, Sakida S. An experimental system for the recovery, accumulation, and utilization of heat generated by bamboo chip biodegradation using a small scale apparatus. Journal Agricultural Meteorology, 2014; 70(1): 1-11.

[82] Fulford B. The composting greenhouse at new alchemy institute: A Report on Two Years of Operation and Monitoring. New Alchemy Institute, Research Report No. 3. 1986.

[83] Smith M M, Aber J D. Heat recovery from compost. Bio Cycle, 2014; 55(2): 26-29.

[84] Smith M M, Aber J D, Rynk R. Heat recovery from composting: A comprehensive review of system design, recovery rate, and utilization. Compost Science \& Utilization, 2016; 12: 2326-2397. 